\title{
CHICACO
}

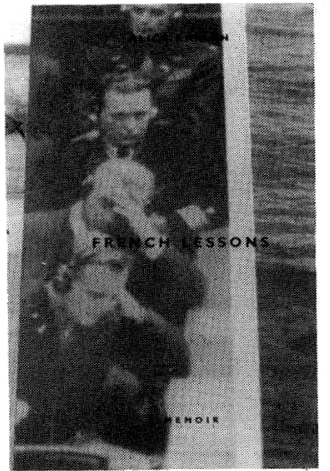

FRENCH LESSONS

A Memoir

Alice Kaplan

Paper $\$ 9.95232$ pages

\section{CULTURAL CAPITAL}

The Problem of Literary

Canon-Formation

John Guillory

Cloth $\$ 36.00408$ pages

\section{SIMPLE AND DIRECT}

A Rhetoric for Writers: Revised Edition

Jacques Barzun

Paper \$14.95 304 pages

PRECISION AND SOUL

Essays and Addresses

Robert Musil

Edited and translated by Burton Pike and David S. Luft

Paper \$16.95 329 pages

\section{GIVEN TIME}

I. Counterfeit Money

Jacques Derrida

Translated by Peggy Kamuf

Paper \$11.95 182 pages

\section{JUSTICE AS}

\section{TRANSLATION}

An Essay in Cultural and Legal Criticism

James Boyd White

Paper \$14.95 332 pages

\section{Now Available in Paperback}

\section{FORMS OF NATIONHOOD}

The Elizabetban Writing of England

Richard Helgerson

Paper \$15.95 375 pages illus.

\section{DESIRE AND TRUTH}

Functions of Plot in

Eighteentb-Century English Novels

Patricia Meyer Spacks

Paper \$14.95 272 pages

\section{EROTIC FAITH}

Being in Love from Jane Austen to D. H. Lawrence

Robert M. Polhemus

Paper \$17.95 371 pages illus.

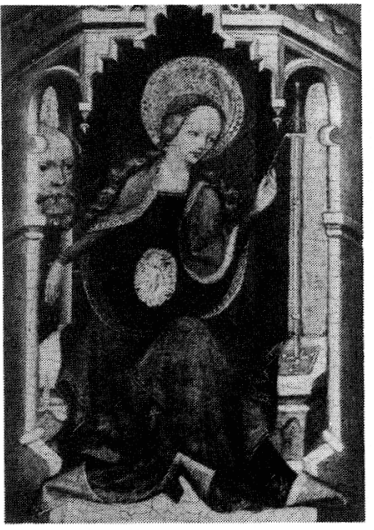

\section{THE THEATER OF} DEVOTION

East Anglian Drama and Society in the Late Middle Ages

Gail McMurray Gibson

Paper \$14.95 268 pages illus.

HOMOSEXUAL

DESIRE IN

SHAKESPEARE'S

\section{ENGLAND}

A Cultural Poetics

Bruce R. Smith

Paper \$14.95 344 pages illus.

\section{CULTURES OF LETTERS}

Scenes of Reading and Writing in

Nineteenth-Century America

Richard H. Brodhead

Paper \$14.95 256 pages

\section{BLACK AND WHITE STRANGERS}

Race and American Literary

Realism

Kenneth W. Warren

Cloth $\$ 27.50178$ pages

Black Literature and Culture Series

\section{RADICAL ARTIFICE}

Writing Poetry in the Age of Media

Marjorie Perloff

Paper \$13.95 264 pages illus.

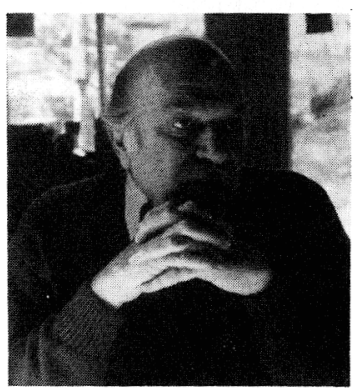

\section{IN QUEST OF THE ORDINARY}

Lines of Skepticism and Romanticism

Stanley Cavell

Paper \$12.95 208 pages

\section{NO PLACE OF GRACE}

Antimodernism and the

Transformation of American Culture, 1880-1920

T. J. Jackson Lears

Paper $\$ 16.95400$ pages

Come visit us at

Booths 204, 206, and 208

for a $\mathbf{2 0 \%}$ meeting discount 


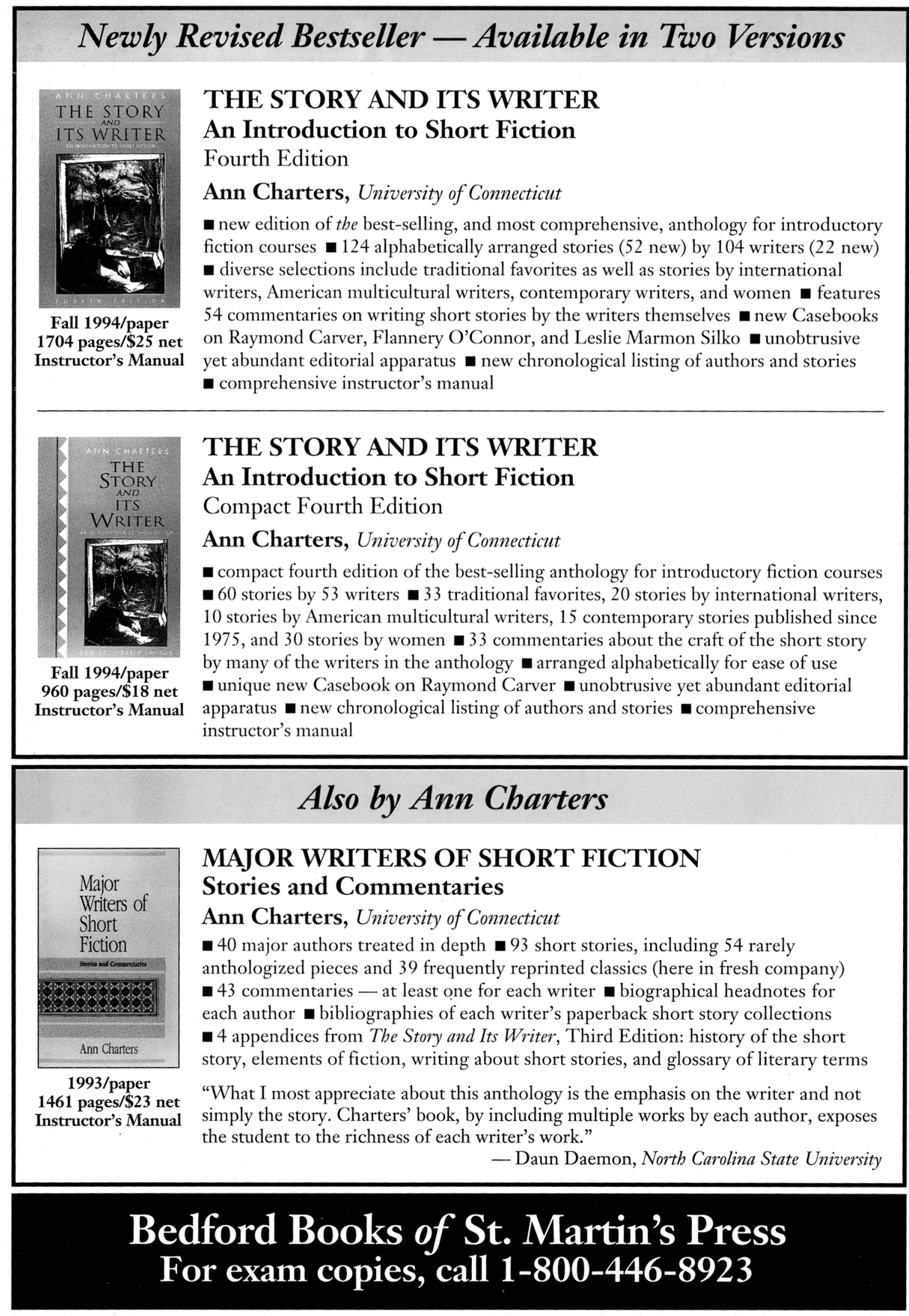

